\title{
Astodrimer sodium and bacterial vaginosis: a mini review
}

\author{
Werner Mendling ${ }^{1}\left(\mathbb{B} \cdot\right.$ Wolfgang Holzgreve $^{2}(\mathbb{C}$
}

Received: 10 November 2021 / Accepted: 28 January 2022 / Published online: 4 March 2022

(c) The Author(s) 2022

\begin{abstract}
Bacterial vaginosis (BV) is the most common vaginal infection affecting women of childbearing age, and is associated with a substantial burden on women's physical, emotional, sexual and social lives, as well as being linked to a number of gynaecological and obstetrical complications and adverse pregnancy outcomes. Antibiotics, such as metronidazole or clindamycin, are recommended as first-line treatment for BV, but may be associated with antibiotic resistance, high rates of recurrence and poor patient treatment satisfaction. Astodrimer sodium gel is a novel, non-antibiotic treatment for BV that is not systemically absorbed. It prevents pathogenic bacteria from adhering to the vaginal wall, and disrupts and inhibits the formation of pathogenic bacterial biofilms. Clinical cure rates of 50-57\% were observed in patients with BV treated with astodrimer sodium compared with $17-21 \%$ treated with placebo $(p<0.001)$ in Phase 3 trials. In a separate Phase 3 trial, recurrence of BV occurred in $44 \%$ of patients treated with astodrimer sodium compared with $54 \%$ of patients who received placebo $(p=0.015)$. Astodrimer sodium is well tolerated, with vulvovaginal candidosis being the only treatment-related adverse event reported to occur more often than with placebo. The availability of astodrimer sodium, a well-tolerated, convenient, non-antibiotic treatment for BV, represents significant progress in the treatment of this burdensome condition.
\end{abstract}

Keywords Bacterial vaginosis $\cdot$ Astodrimer sodium $\cdot$ Vaginal gel $\cdot$ Non-antibiotic treatment

\section{Introduction}

Bacterial vaginosis (BV) is the most common vaginal syndrome affecting women of childbearing age $[1,2]$. It is characterised by foul-smelling vaginal discharge and may sometimes also be accompanied by dysuria, dyspareunia, burning and vaginal inflammation [3, 4]. Additionally, BV is a major cause of complications affecting the reproductive health of women $[1,5,6]$.

Oral or intravaginal antibiotics are currently recommended as first-line treatment for BV, including persistent or recurrent BV $[7,8]$. However effective, there is potential for development of antibiotic resistance with these treatments [9-11]. In addition, BV symptoms often recur soon after treatment has ended, with patients reporting low

Werner Mendling

w.mendling@t-online.de

1 German Centre for Infections in Gynecology and Obstetrics at Landesfrauenklinik, Helios University Hospital Wuppertal, Heusnerstrasse 40, 42283 Wuppertal, Germany

2 Wolfgang Holzgreve, University Hospital Bonn, Venusberg-Campus 1, 53127 Bonn, Germany treatment satisfaction and a dislike of taking antibiotics [12]. Non-antibiotic treatments and probiotics have been investigated for the treatment of $\mathrm{BV}$ with varying degrees of success [13-15].

More recently, a number of clinical trials investigating a novel non-antibiotic treatment, astodrimer sodium, have been published, and astodrimer sodium is now available for the treatment and prevention of recurrent BV [16-18]. This mini review will provide a brief overview of the epidemiology and pathophysiology of BV before summarising the findings of the astodrimer sodium clinical trials.

\section{Pathophysiology and epidemiology of bacterial vaginosis}

\section{Pathophysiology of bacterial vaginosis}

The 'normal' vaginal flora comprises a mixture of more than five hundred species of bacteria kept in balance by different lactobacilli $[19,20]$. These bacteria provide numerical dominance, preventing harmful bacteria from gaining a foothold [1]. The most prevalent are usually Lactobacillus 
species [20-23], but the distribution of species varies significantly between ethnicities and between women of the same ethnicity [24-26]. Lactobacilli produce lactic acid and hydrogen peroxide that maintain a normal, acidic vaginal $\mathrm{pH}$ (3.5-4.5); the acidic environment inhibits the growth of pathogens and protects against infections [20,27].

A wide range of factors, including sexual habits, smoking and personal hygiene habits [20,28], can increase the vaginal $\mathrm{pH}$, making conditions unfavourable for Lactobacilli and allowing the growth of predominantly anaerobic bacteria such as Gardnerella vaginalis, resulting in BV [27]. Some $G$. vaginalis strains can then form a biofilm with other bacteria $[29,30]$, which provides protection from lactic acid and hydrogen peroxide [31], and can lead to recurrent episodes of BV.

\section{Signs and symptoms of bacterial vaginosis}

It is estimated that $50-75 \%$ of women with BV are asymptomatic [32-35]; those with symptoms typically present with an off-white, thin, homogeneous vaginal discharge and a "fishy" vaginal odour [35, 36]. Patients may also have vulvar or vaginal pruritus, burning and irritation $[3,36]$.

\section{Diagnosis of bacterial vaginosis}

Diagnosis of BV is generally made using the Amsel clinical criteria [32] or the laboratory-based Nugent scoring system [37].

The Amsel clinical criteria require three of the following four symptoms or signs for a positive diagnosis: an adherent, homogeneous, white discharge that coats the vaginal wall; a raised vaginal $\mathrm{pH}$ of $>4.5$; a positive "whiff amine test" upon addition of potassium hydroxide to the discharge and/ or the presence of clue cells upon the wet mount [32]. Clue cells are vaginal epithelial cells covered by adherent gramnegative rods [38].

Nugent's scoring system assesses the number of Gardnerella morphotypes, gram-variable rods, and Lactobacillus morphotypes, giving an overall score out of 10 that predicts the likelihood of BV [37]. A score of 7 or more is indicative of BV.

\section{Epidemiology of bacterial vaginosis}

According to a recent meta-analysis, BV is estimated to affect $23-29 \%$ of reproductive-aged women in the general population worldwide [2]. Globally, there are considerable differences between geographic regions and ethnic populations, with the highest prevalence in South Asian women (28.7\%) and the lowest prevalence in European and Central Asian women (22.8\%). Within North America, black and Hispanic women had significantly higher BV prevalence
(33.2\% and $30.7 \%$, respectively) than other ethnic groups (white: $22.7 \%$; Asian: $11.1 \%$; $p=0.001$ ). The prevalence of BV among pregnant women was similar to the general population overall (11.7-33.2\%), while it was higher among women living with human immunodeficiency virus (35.6\% vs $25.6 \%$; $p=0.054$ ) [2].

Risk factors for BV include new and higher numbers of male and female partners, young age of first intercourse [39-44], lack of condom use [39,45], presence of other sexually transmitted infections [44], smoking [28, 43], drinking alcohol [28], and frequent douching/vaginal cleansing $[28,42,43,45]$.

\section{Burden and complications of bacterial vaginosis}

Around two-thirds of women with recurrent BV report a moderate to severe impact on their physical, emotional, sexual and social lives [3]. Malodour is reported to be the most distressing symptom, although many women also find the discharge distressing. Women with recurrent BV reported feeling embarrassed, self-conscious and uncomfortable, and they reported that they were always worrying about BV. The biggest impact of BV was on women's sex lives and practices, with sexual self-esteem, confidence and levels of intimacy also affected [3].

Recurrent BV is common, with $58-76 \%$ of women who have undergone metronidazole treatment reporting recurrence within 12 months [46-48]. A study aiming to predict the likelihood of recurrence showed that a higher pre-treatment abundance of Lactobacillus spp. relative to $\mathrm{BV}$-associated species was linked with a higher likelihood of recurrence due to sequestration of metronidazole [49]. Conversely, another study found that persistently high titres of Gardnerella Gsp07 and/or G. swidsinskii / G. leopoldii were associated with refractory/recurrent BV [50].

As well as being associated with poor levels of effectiveness, women reported frustration and dissatisfaction with current available treatments for BV [12]. In addition, women reported low levels of satisfaction with the clinical management of $\mathrm{BV}$, including inconsistent advice, misdiagnosis, inappropriate diagnostic approaches and insensitive or dismissive attitudes. These frustrations led many women to try self-help remedies and lifestyle modifications, including the high-risk practice of douching.

BV is associated with a number of obstetric complications and adverse pregnancy outcomes. In various studies, BV has been associated with an increased risk of preterm delivery [51-55], premature rupture of membranes [55], low birthweight $[52,55]$, early spontaneous abortion $[51,56$, 57], late miscarriage [53], and maternal infection [51, 53, 55]. In addition, BV has been associated with pelvic inflammatory disease, including endometriosis $[6,58]$, infertility $[6,56,59]$, and sexually transmitted diseases $[5,58,60-62]$. 


\section{Guidelines for the treatment of bacterial vaginosis}

Guidelines from the International Union against Sexually Transmitted Infection (IUSTI) and World Health Organization (WHO) on the management of vaginal discharge were published in 2018 and address BV [7]. The guidelines recommend 5-7 days of oral metronidazole $400-500 \mathrm{mg}$ twice daily, intravaginal metronidazole gel $(0.75 \%)$ once daily for 5 days, or intravaginal clindamycin cream (2\%) once daily for 7 days, as first-line therapy for uncomplicated BV (grade 1 recommendation; grade A quality of evidence) [7]. Alternative regimens include metronidazole $2 \mathrm{~g}$ orally in a single dose, tinidazole $2 \mathrm{~g}$ orally in a single dose or $1 \mathrm{~g}$ orally for 5 days, clindamycin $300 \mathrm{mg}$ orally twice daily for 7 days, or dequalinium chloride $10 \mathrm{mg}$ vaginal tablets once daily for 6 days. For recurrent and persistent BV, IUSTI/WHO guidelines recommend that the current best treatment is intravaginal metronidazole, but the strength of recommendation is grade 2 , and the quality of evidence is grade B [7].

Other relevant guidelines include those of the Association of the Scientific Medical Societies in Germany (AWMF; Arbeitsgemeinschaft der Wissenschaftlichen Medizinischen Fachgesellschaften), which were published in 2014. These guidelines also recommend oral or vaginal metronidazole or intravaginal clindamycin cream [8]. They also report evidence for prevention of recurrence with dequalinium chloride vaginal tablets and nifuratel vaginal tablets [8].

\section{Astodrimer sodium vaginal gel for bacterial vaginosis}

\section{Mechanism of action}

Astodrimer sodium is a dendrimer, a class of compounds characterised by a highly branched, three-dimensional architecture [16]. The core of astodrimer sodium is made of the benzhydrylamine amide of L-lysine, to which four successive layers of L-lysine branching units are added, creating a dendrimer with 32 amine groups on the surface. Finally, sodium 1-(carboxymethoxy) naphthalene3,6-disulphonate groups are attached to each of the amine surface groups $[63,64]$. This process results in a large molecule $(16,581 \mathrm{Da})$ with a negative surface charge, which is not systemically absorbed [16, 63].

Astodrimer sodium is formulated in an aqueous, Carbopol $^{\circledR}$-based, muco-adhesive gel [63]. It inhibits the growth of bacteria associated with BV by blocking their attachment to cells, and can inhibit the formation of, and disrupt existing, biofilms (Fig. 1). As noted earlier, biofilms are an important factor in the pathogenesis of BV, and are not well managed by existing therapies. This situation leads to inadequate treatment and the potential for recurrence [16]. Preclinical studies in a range of in vitro and animal models demonstrated that astodrimer was non-toxic at clinically relevant doses and well tolerated [65-68].

\section{Astodrimer sodium for the treatment of bacterial vaginosis}

Astodrimer sodium was investigated as a treatment for BV in a Phase 2 study that enrolled 132 women with BV who were randomised to astodrimer sodium $0.5 \%, 1 \%$, or $3 \%$, or hydroxyethyl cellulose placebo gel at a dose of $5 \mathrm{~g}$ vaginally once daily for 7 days. The primary endpoint was clinical cure at study Days 21-30 [16].

Clinical cure rates at Day 21-30 were $28.0 \%, 46.2 \%$, $23.3 \%$, and $11.5 \%$ with the $0.5 \%, 1 \%$, and $3 \%$ astodrimer doses, and placebo, respectively ( $p=0.006$ for $1 \%$ gel vs placebo). At Day 9-12, clinical cure rates with astodrimer sodium were superior to placebo, with rates of $62.5 \%$, $74.1 \%, 55.2 \%$, and $22.2 \%$ with the $0.5 \%, 1 \%$, and $3 \%$ astodrimer doses, and placebo, respectively ( $p<0.001$ for $1 \%$ gel vs placebo) [16].

Adverse events (AEs) considered possibly related to treatment occurred in $25.0 \%, 18.8 \%$, and $31.0 \%$ of astodrimer $0.5 \%, 1 \%$, and $3 \%$ gel-treated patients, respectively, and $21.9 \%$ of placebo patients. Patients found astodrimer gel to be acceptable and were satisfied with treatment, as shown by significantly higher scores compared with placebo on the Treatment Satisfaction Questionnaire for Medicine (TQSM) for effectiveness and Global Satisfaction. Scores for convenience and tolerability were similar between the astodrimer and placebo groups [16].

Two Phase 3 studies were conducted to confirm the efficacy and safety of astodrimer sodium $1 \%$ gel for the treatment of BV. Study 1 was conducted in the US and Study 2 was conducted in the US, Germany and Belgium [17]. In both studies, patients were randomised 1:1 to astodrimer $1 \%$ gel or placebo at a dose of $5 \mathrm{~g}$ vaginally once daily for 7 days. In Study 1, 127 patients were randomised to astodrimer and 123 to placebo, and in Study 2, 128 patients were randomised to astodrimer and 123 to placebo. The primary endpoint was clinical cure at Day 9-12.

Astodrimer was superior to placebo for the primary endpoint and some of the secondary endpoints. Clinical cure rates at Day 9-12 were $50.4 \%$ vs $16.5 \%(p<0.001$; Study 1$)$ and $56.7 \%$ vs $21.4 \%$ ( $p<0.001$; Study 2 ) for astodrimer compared with placebo. Nugent cure rates at Day $9-12$ were $12.8 \%$ vs $2.6 \%(p=0.004$; Study 1$)$ and $13.3 \%$ 

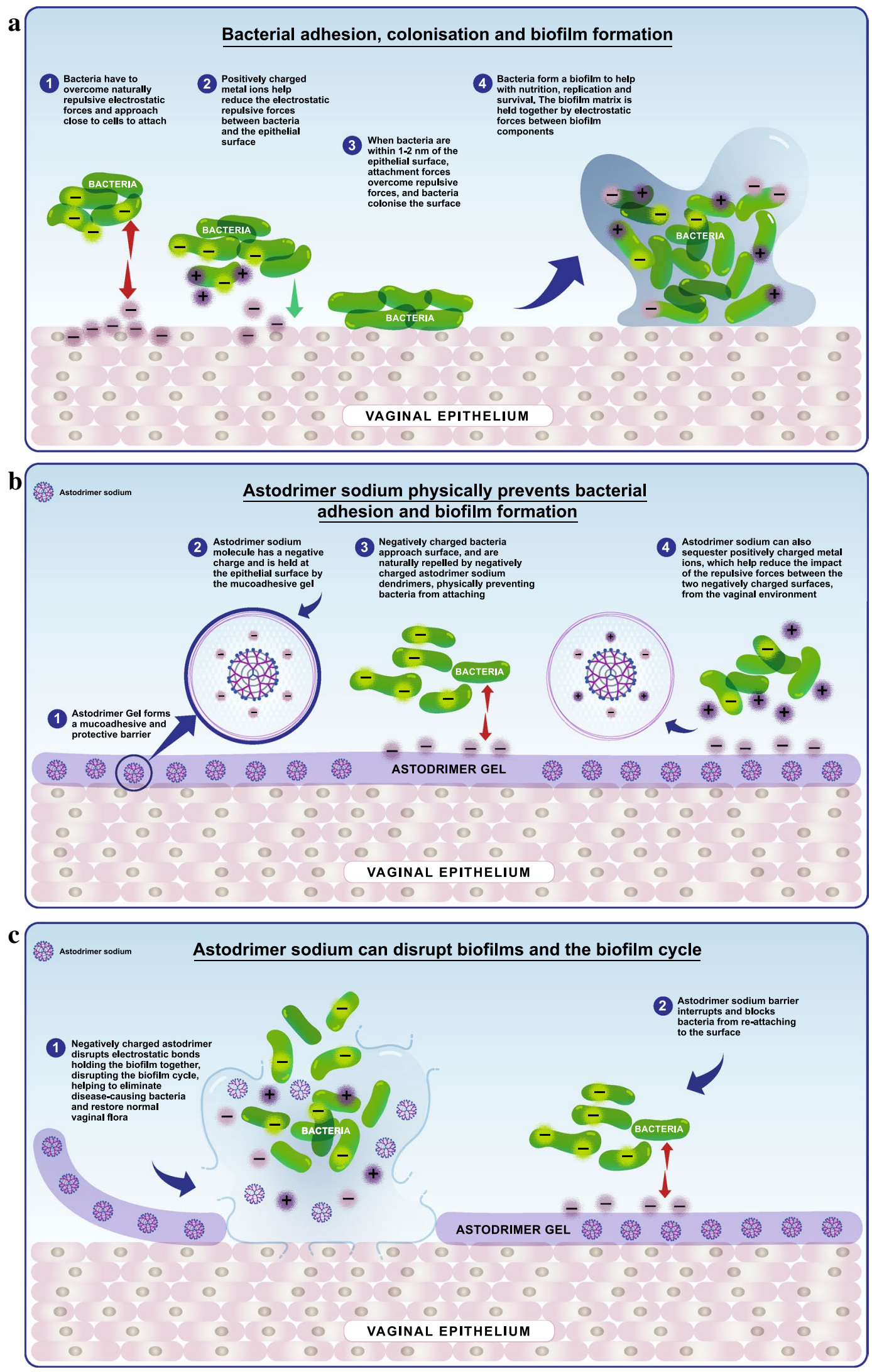
४Fig. 1 Antibacterial mechanism of action of astodrimer sodium. a Bacteria attach to and colonise the vaginal epithelium, forming a biofilm. b Astodrimer Gel containing astodrimer sodium, forms a barrier that blocks bacteria from attaching to the vaginal epithelium. c Astodrimer sodium also disrupts biofilms. (C) Starpharma Pty Ltd, 2021

vs $5.1 \%$ ( $p=0.030$; Study 2 ) for astodrimer compared with placebo. The differences between the astodrimer and placebo groups were smaller at the follow-up visit on Day 21-30, but still favoured astodrimer and were statistically significant in some cases. More women receiving astodrimer reported absence of vaginal discharge and absence of vaginal odour at Day 21-30 compared with placebo (discharge: $52.1 \%$ vs $37.4 \%, p=0.023$ for Study 1, 60.0\% vs $50.4 \%, p=0.131$ for Study 2; odour: $52.1 \%$ vs $44.3 \%, p=0.222$ for Study $1,63.3 \%$ vs $37.4 \%, p=0.006$ for Study 2). When the primary analysis of clinical cure at Day 9-12 was conducted in patients with a baseline Nugent score $\geq 7$, astodrimer was also superior to placebo: $52.7 \%$ vs $17.3 \%, p<0.001$ in Study 1 ; and $57.5 \%$ vs $14 \%, p<0.001$ in Study 2 [17].

The studies were combined to assess safety and tolerability. The overall incidence of AEs was $42.9 \%$ for astodrimer and $41.4 \%$ for placebo, and AEs possibly related to treatment were reported by $14.7 \%$ of patients who received astodrimer and $9.4 \%$ of patients who received placebo. The most common AEs reported, irrespective of relationship to treatment, were headache $(7.5 \%$ in the astodrimer group and $7.0 \%$ in the placebo group), vulvovaginal candidosis $(6.0 \%$ and $3.7 \%$, respectively) and vulvovaginal pruritus (5.2\% and $4.5 \%$, respectively). Vulvovaginal candidosis considered potentially related to study treatment occurred in $2.4 \%$ of astodrimer-treated patients but no placebo-treated patients. Urinary tract infections (irrespective of treatment relationship) were reported in $1.6 \%$ of the astodrimer group and $1.2 \%$ of the placebo group [17].

Following the publication of these data, a meta-analysis was conducted to examine the efficacy and safety of astodrimer gel for BV [69]. For efficacy outcomes, it included the Phase 2 and 3 studies discussed above. The meta-analysis found that astodrimer gel was significantly superior to placebo for all pooled efficacy outcomes, including: clinical cure rate [pooled risk ratio (RR) $2.10,95 \%$ confidence interval [CI] 1.76-2.51; $p<0.01]$; microbiological Nugent cure rate (RR 4.41, 95\% CI 2.49-7.81; $p<0.01$ ); patient self-reported absence of vaginal odour (RR $1.5795 \%$ CI $1.40-1.77 ; p<0.01)$ and discharge (RR $1.45,95 \%$ CI $1.29-1.64 ; p<0.01$ ); resolution of Amsel criteria (all criteria $p<0.01)$ and proportion of patients who did not require rescue therapy (RR 1.68, 95\% CI 1.13-2.51; $p=0.01$ ).

The safety outcomes were investigated in the three treatment studies and the prevention of recurrence Phase 3 study discussed below [18]. The meta-analysis found that astodrimer had similar tolerability to placebo for all pooled safety endpoints with the exception of vulvovaginal candidosis (RR 1.427, 95\% CI 1.025-1.986; $p=0.035$ ) and treatment-related vulvovaginal candidosis (RR 1.181, 95\% CI 1.020-3.239; $p=0.043$ ). When compared with placebo, the incidence of severe AEs was significantly lower in the astodrimer group (RR $0.373,95 \%$ CI $0.146-0.950$; $p=0.039$ ) [69].

\section{Astodrimer sodium for prevention of recurrent bacterial vaginosis}

In order to demonstrate the efficacy and safety of astodrimer sodium $1 \%$ gel to prevent recurrence of BV, a large Phase 3 study was conducted [18]. A total of 864 women with BV and a history of recurrent BV were enrolled and received oral metronidazole $500 \mathrm{mg}$ twice daily for 7 days. Successfully-treated women were then randomised 1:1 to receive astodrimer sodium $1 \%$ gel or placebo at a dose of $5 \mathrm{~g}$ vaginally every second day for 16 weeks, followed by a further 12 weeks off-treatment. The primary endpoint was recurrence of BV (presence of $\geq 3$ Amsel criteria) at or by Week 16 [18].

Astodrimer sodium was superior to placebo for the primary and many of the secondary endpoints. For the primary endpoint, recurrence occurred in $44.2 \%$ of patients who received astodrimer compared with $54.3 \%$ of patients who received placebo $(p=0.015)$. Time to recurrence of BV was significantly longer for women receiving astodrimer compared with placebo, with Kaplan-Meier curves separating after Week 4 and remaining so until Week $16(p=0.007)$. Recurrence of all individual Amsel criteria at or by Week 16 was lower in the astodrimer group compared with placebo with the exception of vaginal fluid $\mathrm{pH}$. Recurrence of subject-reported symptoms at or by Week 16 was also significantly lower in the astodrimer group versus placebo (vaginal discharge in $20.4 \%$ vs $28.6 \%$, RR $0.71,95 \%$ CI $0.53-0.96$, $p=0.025$; vaginal odour in $20.7 \%$ vs $31.5 \%$, RR $0.66,95 \%$ CI 0.49-0.88, $p=0.004$ ) [18].

During the 12-week follow-up phase, recurrence of BV was lower in the astodrimer group than the placebo group, but the differences were not statistically significant. Recurrence of BV symptoms of vaginal odour and/or discharge was significantly lower in the astodrimer arm versus placebo up to 8 weeks after cessation of therapy (Week $24,36.1 \%$ vs $45.5 \%, p=0.027$ ) [18].

The overall incidence of AEs was $54.1 \%$ with astodrimer and $47.4 \%$ with placebo. Potentially treatment-related AEs occurred in $12.6 \%$ of astodrimer-treated patients and $11.3 \%$ of placebo-treated patients. The most common AEs during treatment were vulvovaginal candidosis $(18.0 \%$ with astodrimer and $13.7 \%$ with placebo), urinary tract infection (7.8\% and $2.4 \%)$ and headache (5.1\% and 6.2\%). 
Potentially treatment-related vulvovaginal candidosis was reported in $6.8 \%$ and $4.8 \%$ of astodrimer- and placebotreated patients, respectively. During follow-up, vulvovaginal candidosis rates were $4.1 \%$ and $5.8 \%$ for astodrimer- and placebo-treated patients, respectively [18].

\section{Conclusions}

This mini-review has highlighted an unmet need for new treatment options in $\mathrm{BV}$, the most common vaginal syndrome affecting women of childbearing age [1,2]. While first-line treatment with antibiotics is recommended and supported by robust evidence [7, 8], there remains potential for the development of antibiotic resistance with repeated exposure to these medications [9] and resistance to polybacterial biofilms in both/all sexual partners [29]. In addition, some patients have reported poor treatment satisfaction and dislike taking antibiotics, particularly on a regular basis [12].

Astodrimer sodium gel is a non-antibiotic treatment for BV that acts locally via a novel mechanism of action by which it inhibits the formation of, and disrupts existing, biofilms [16]. It is not systemically absorbed and is formulated in a muco-adhesive gel [16]. It treats BV, restores vaginal flora balance, and normalises vaginal $\mathrm{pH}$; it also effectively prevents recurrent BV and its symptoms [70]. Astodrimer sodium provides rapid relief of vaginal discomfort such as unpleasant odour and discharge, and offers a convenient once daily or every second day vaginal application, depending on the indication [70].

The use of Astodrimer sodium gel in the treatment and prevention of BV is supported by high-quality clinical trial data demonstrating superior efficacy compared with placebo [16-18]. It is also well tolerated in terms of AEs, and was acceptable to women in terms of treatment satisfaction [16-18].

\section{Future perspectives}

Astodrimer sodium has the potential to improve outcomes for patients with $\mathrm{BV}$, as it is a non-antibiotic treatment with no potential to cause antibiotic resistance, is not systemically absorbed and is also convenient. It is formulated as a transparent gel that adheres to the vaginal wall, thus avoiding leakage from the vagina, which can be an inconvenience associated with other topical treatments. The availability of a well-tolerated, convenient non-antibiotic treatment for BV represents significant progress in the treatment of BV and may benefit women affected by this widespread condition.

Acknowledgements Editorial support by Makara Health, UK was funded by Mundipharma Medical GmbH, Switzerland.
Authors' contributions WM and WH wrote the manuscript.

Funding Not applicable.

Availability of data and material All referenced publications are in the public domain.

\section{Declarations}

Conflict of interest WM and WH are Members of the scientific advisory board of Mundipharma Medical GmbH, Basel, Switzerland.

Ethics approval All referenced studies should have obtained the appropriate ethics approval.

Open Access This article is licensed under a Creative Commons Attribution 4.0 International License, which permits use, sharing, adaptation, distribution and reproduction in any medium or format, as long as you give appropriate credit to the original author(s) and the source, provide a link to the Creative Commons licence, and indicate if changes were made. The images or other third party material in this article are included in the article's Creative Commons licence, unless indicated otherwise in a credit line to the material. If material is not included in the article's Creative Commons licence and your intended use is not permitted by statutory regulation or exceeds the permitted use, you will need to obtain permission directly from the copyright holder. To view a copy of this licence, visit http://creativecommons.org/licenses/by/4.0/.

\section{References}

1. Turovskiy Y, Sutyak Noll K, Chikindas ML (2011) The aetiology of bacterial vaginosis. J Appl Microbiol 110:1105-1128. https:// doi.org/10.1111/j.1365-2672.2011.04977.x

2. Peebles K, Velloza J, Balkus JE, McClelland RS, Barnabas RV (2019) High global burden and costs of bacterial vaginosis: a systematic review and meta-analysis. Sex Transm Dis 46:304-311. https://doi.org/10.1097/OLQ.0000000000000972

3. Bilardi JE, Walker S, Temple-Smith M, McNair R, Mooney-Somers J, Bellhouse C et al (2013) The burden of bacterial vaginosis: Women's experience of the physical, emotional, sexual and social impact of living with recurrent bacterial vaginosis. PLoS ONE 8:e74378. https://doi.org/10.1371/journal.pone.0074378

4. Centers for Disease Control and Prevention. Bacterial Vaginosis 2021 [Available from: https://www.cdc.gov/std/treatment-guide lines/bv.htm.

5. Chen X, Lu Y, Chen T, Li R (2021) The female vaginal microbiome in health and bacterial vaginosis. Front Cell Infect Microbiol 11:631972. https://doi.org/10.3389/fcimb.2021.631972

6. Ravel J, Moreno I, Simon C (2021) Bacterial vaginosis and its association with infertility, endometritis, and pelvic inflammatory disease. Am J Obstet Gynecol 224:251-257. https://doi.org/10. 1016/j.ajog.2020.10.019

7. Sherrard J, Wilson J, Donders G, Mendling W, Jensen JS (2018) 2018 European (IUSTI/WHO) international union against sexually transmitted infections (IUSTI) World Health Organisation (WHO) guideline on the management of vaginal discharge. Int J STD AIDS 29:1258-1272. https://doi.org/10.1177/0956462418 785451

8. Mendling W, Martius J, Hoyme UB (2014) S1-guideline on bacterial vaginosis in gynecology and obstetrics: long version-AWMF guideline, registration no. 015/028, July 2013 
Langfassung-AWMF-Register Nr. 015/028, Juli 2013. Geburtshilfe Frauenheilkd 74:51-54. https://doi.org/10.1055/s-00331360230

9. Austin MN, Beigi RH, Meyn LA, Hillier SL (2005) Microbiologic response to treatment of bacterial vaginosis with topical clindamycin or metronidazole. J Clin Microbiol 43:4492-4497. https:// doi.org/10.1128/JCM.43.9.4492-4497.2005

10. Beigi RH, Austin MN, Meyn LA, Krohn MA, Hillier SL (2004) Antimicrobial resistance associated with the treatment of bacterial vaginosis. Am J Obstet Gynecol 191:1124-1129. https://doi.org/ 10.1016/j.ajog.2004.05.033

11. Joseph RJ, Ser HL, Kuai YH, Tan LT, Arasoo VJT, Letchumanan $\mathrm{V}$ et al (2021) Finding a balance in the vaginal microbiome: how do we treat and prevent the occurrence of bacterial vaginosis? Antibiotics (Basel). https://doi.org/10.3390/antibiotics10060719

12. Bilardi J, Walker S, McNair R, Mooney-Somers J, TempleSmith M, Bellhouse C et al (2016) Women's management of recurrent bacterial vaginosis and experiences of clinical care: a qualitative study. PLoS ONE 11:e0151794. https://doi.org/10. 1371/journal.pone.0151794

13. Kumar N, Behera B, Sagiri SS, Pal K, Ray SS, Roy S (2011) Bacterial vaginosis: etiology and modalities of treatment-A brief note. J Pharm Bioallied Sci 3:496-503. https://doi.org/10. 4103/0975-7406.90102

14. Truter I, Graz M (2013) Bacterial vaginosis: literature review of treatment options with specific emphasis on non-antibiotic treatment. Afr J Pharm Pharmacol 7:3060-3067. https://doi.org/ 10.5897/ajppx2013.0001

15. Wang Z, He Y, Zheng Y (2019) Probiotics for the treatment of bacterial vaginosis: a meta-analysis. Int J Environ Res Public Health. https://doi.org/10.3390/ijerph16203859

16. Waldbaum AS, Schwebke JR, Paull JRA, Price CF, Edmondson SR, Castellarnau A et al (2020) A phase 2, double-blind, multicenter, randomized, placebo-controlled, dose-ranging study of the efficacy and safety of Astodrimer Gel for the treatment of bacterial vaginosis. PLoS ONE 15:e0232394. https://doi.org/ 10.1371/journal.pone.0232394

17. Chavoustie SE, Carter BA, Waldbaum AS, Donders GGG, Peters KH, Schwebke JR et al (2020) Two phase 3, doubleblind, placebo-controlled studies of the efficacy and safety of Astodrimer $1 \% \mathrm{Gel}$ for the treatment of bacterial vaginosis. Eur J Obstet Gynecol Reprod Biol 245:13-18. https://doi.org/10. 1016/j.ejogrb.2019.11.032

18. Schwebke JR, Carter BA, Waldbaum AS, Agnew KJ, Paull JRA, Price CF et al (2021) A phase 3, randomized, controlled trial of Astodrimer 1\% Gel for preventing recurrent bacterial vaginosis. Eur J Obstet Gynecol Reprod Biol X 10:100121. https://doi.org/ 10.1016/j.eurox.2021.100121

19. Diop K, Dufour JC, Levasseur A, Fenollar F (2019) Exhaustive repertoire of human vaginal microbiota. Hum Microbiome J 11:100051

20. Mendling W (2016) Normal and abnormal vaginal microbiota. LaboratoriumsMedizin 40:239-246. https://doi.org/10.1515/ labmed-2016-0011

21. Fredricks DN, Fiedler TL, Marrazzo JM (2005) Molecular identification of bacteria associated with bacterial vaginosis. N Engl J Med 353:1899-1911. https://doi.org/10.1056/nejmoa043802

22. Ling Z, Kong J, Liu F, Zhu H, Chen X, Wang Y et al (2010) Molecular analysis of the diversity of vaginal microbiota associated with bacterial vaginosis. BMC Genom 11:488. https://doi. org/10.1186/1471-2164-11-488

23. Lamont RF, Sobel JD, Akins RA, Hassan SS, Chaiworapongsa T, Kusanovic JP et al (2011) The vaginal microbiome: new information about genital tract flora using molecular based techniques. BJOG 118:533-549. https://doi.org/10.1111/j.14710528.2010.02840.x
24. Ravel J, Gajer P, Abdo Z, Schneider GM, Koenig SS, McCulle SL et al (2011) Vaginal microbiome of reproductive-age women. Proc Natl Acad Sci U S A 108(Suppl 1):4680-4687. https://doi.org/10.1073/pnas.1002611107

25. Jespers V, Menten J, Smet H, Poradosu S, Abdellati S, Verhelst $R$ et al (2012) Quantification of bacterial species of the vaginal microbiome in different groups of women, using nucleic acid amplification tests. BMC Microbiol 12:83. https://doi.org/10. 1186/1471-2180-12-83

26. Drell T, Lillsaar T, Tummeleht L, Simm J, Aaspollu A, Vain E et al (2013) Characterization of the vaginal micro- and mycobiome in asymptomatic reproductive-age Estonian women. PLoS ONE 8:e54379. https://doi.org/10.1371/journal.pone.0054379

27. Amabebe E, Anumba DOC (2018) The vaginal microenvironment: the physiologic role of lactobacilli. Front Med (Lausanne) 5:181. https://doi.org/10.3389/fmed.2018.00181

28. Ranjit E, Raghubanshi BR, Maskey S, Parajuli P (2018) Prevalence of bacterial vaginosis and its association with risk factors among nonpregnant women: a hospital based study. Int J Microbiol 2018:8349601. https://doi.org/10.1155/2018/8349601

29. Swidsinski A, Loening-Baucke V, Mendling W, Dorffel Y, Schilling J, Halwani Z et al (2014) Infection through structured polymicrobial Gardnerella biofilms (StPM-GB). Histol Histopathol 29:567-587. https://doi.org/10.14670/HH-29.10.567

30. Muzny CA, Taylor CM, Swords WE, Tamhane A, Chattopadhyay D, Cerca N et al (2019) An updated conceptual model on the pathogenesis of bacterial vaginosis. J Infect Dis 220:13991405. https://doi.org/10.1093/infdis/jiz342

31. Udayalaxmi BG, Kotigadde S, Kotian S (2012) Effect of pH on the adherence, surface hydrophobicity and the biofilm formation of Gardnerella vaginalis. J Clin Diag Res 6:967-969

32. Amsel R, Totten PA, Spiegel CA, Chen KC, Eschenbach D, Holmes KK (1983) Nonspecific vaginitis. Diagnostic criteria and microbial and epidemiologic associations. Am J Med 74:14-22. https://doi.org/10.1016/0002-9343(83)91112-9

33. Schaaf VM, Perez-Stable EJ, Borchardt K (1990) The limited value of symptoms and signs in the diagnosis of vaginal infections. Arch Intern Med 150:1929-1933

34. Klebanoff MA, Schwebke JR, Zhang J, Nansel TR, Yu KF, Andrews WW (2004) Vulvovaginal symptoms in women with bacterial vaginosis. Obstet Gynecol 104:267-272. https://doi. org/10.1097/01.AOG.0000134783.98382.b0

35. Hoffmann JN, You HM, Hedberg EC, Jordan JA, McClintock MK (2014) Prevalence of bacterial vaginosis and Candida among postmenopausal women in the United States. J Gerontol B Psychol Sci Soc Sci 69:S205-S214. https://doi.org/10.1093/geronb/gbu105

36. Anderson MR, Klink K, Cohrssen A (2004) Evaluation of vaginal complaints. JAMA 291:1368-1379. https://doi.org/10.1001/jama. 291.11.1368

37. Nugent RP, Krohn MA, Hillier SL (1991) Reliability of diagnosing bacterial vaginosis is improved by a standardized method of gram stain interpretation. J Clin Microbiol 29:297-301. https:// doi.org/10.1128/jcm.29.2.297-301.1991

38. Cook RL, Reid G, Pond DG, Schmitt CA, Sobel JD (1989) Clue cells in bacterial vaginosis: immunofluorescent identification of the adherent gram-negative bacteria as Gardnerella vaginalis. J Infect Dis 160:490-496. https://doi.org/10.1093/infdis/160.3.490

39. Fethers KA, Fairley CK, Hocking JS, Gurrin LC, Bradshaw CS (2008) Sexual risk factors and bacterial vaginosis: a systematic review and meta-analysis. Clin Infect Dis 47:1426-1435. https:// doi.org/10.1086/592974

40. Forcey DS, Vodstrcil LA, Hocking JS, Fairley CK, Law M, McNair RP et al (2015) Factors associated with bacterial vaginosis among women who have sex with women: a systematic review. PLoS ONE 10:e0141905. https://doi.org/10.1371/journal.pone. 0141905 
41. Fethers KA, Fairley CK, Morton A, Hocking JS, Hopkins C, Kennedy LJ et al (2009) Early sexual experiences and risk factors for bacterial vaginosis. J Infect Dis 200:1662-1670. https://doi.org/ $10.1086 / 648092$

42. Muzny CA, Sunesara IR, Austin EL, Mena LA, Schwebke JR (2013) Bacterial vaginosis among African American women who have sex with women. Sex Transm Dis 40:751-755. https://doi. org/10.1097/OLQ.0000000000000004

43. Koumans EH, Sternberg M, Bruce C, McQuillan G, Kendrick J, Sutton $M$ et al (2007) The prevalence of bacterial vaginosis in the United States, 2001-2004; associations with symptoms, sexual behaviors, and reproductive health. Sex Transm Dis 34:864-869. https://doi.org/10.1097/OLQ.0b013e318074e565

44. Morris MC, Rogers PA, Kinghorn GR (2001) Is bacterial vaginosis a sexually transmitted infection? Sex Transm Infect 77:63-68. https://doi.org/10.1136/sti.77.1.63

45. Guedou FA, Van Damme L, Deese J, Crucitti T, Becker M, Mirembe $\mathrm{F}$ et al (2013) Behavioural and medical predictors of bacterial vaginosis recurrence among female sex workers: longitudinal analysis from a randomized controlled trial. BMC Infect Dis 13:208. https://doi.org/10.1186/1471-2334-13-208

46. Sobel JD, Schmitt C, Meriwether C (1993) Long-term follow-up of patients with bacterial vaginosis treated with oral metronidazole and topical clindamycin. J Infect Dis 167:783-784. https:// doi.org/10.1093/infdis/167.3.783

47. Bradshaw CS, Morton AN, Hocking J, Garland SM, Morris MB, Moss LM et al (2006) High recurrence rates of bacterial vaginosis over the course of 12 months after oral metronidazole therapy and factors associated with recurrence. J Infect Dis 193:1478-1486. https://doi.org/10.1086/503780

48. Sobel JD, Kaur N, Woznicki NA, Boikov D, Aguin T, Gill G et al (2019) Prognostic indicators of recurrence of bacterial vaginosis. J Clin Microbiol. https://doi.org/10.1128/JCM.00227-19

49. Lee CY, Cheu RK, Lemke MM, Gustin AT, France MT, Hampel B et al (2020) Quantitative modeling predicts mechanistic links between pre-treatment microbiome composition and metronidazole efficacy in bacterial vaginosis. Nat Commun 11:6147. https:// doi.org/10.1038/s41467-020-19880-w

50. Turner E, Sobel JD, Akins RA (2021) Prognosis of recurrent bacterial vaginosis based on longitudinal changes in abundance of Lactobacillus and specific species of Gardnerella. PLoS ONE 16:e256445. https://doi.org/10.1371/journal.pone.0256445

51. Leitich H, Bodner-Adler B, Brunbauer M, Kaider A, Egarter C, Husslein P (2003) Bacterial vaginosis as a risk factor for preterm delivery: a meta-analysis. Am J Obstet Gynecol 189:139-147. https://doi.org/10.1067/mob.2003.339

52. Svare JA, Schmidt H, Hansen BB, Lose G (2006) Bacterial vaginosis in a cohort of Danish pregnant women: prevalence and relationship with preterm delivery, low birthweight and perinatal infections. BJOG 113:1419-1425. https://doi.org/10.1111/j.14710528.2006.01087.x

53. Leitich H, Kiss H (2007) Asymptomatic bacterial vaginosis and intermediate flora as risk factors for adverse pregnancy outcome. Best Pract Res Clin Obstet Gynaecol 21:375-390. https://doi.org/ 10.1016/j.bpobgyn.2006.12.005

54. Menard JP, Mazouni C, Salem-Cherif I, Fenollar F, Raoult D, Boubli L et al (2010) High vaginal concentrations of Atopobium vaginae and Gardnerella vaginalis in women undergoing preterm labor. Obstet Gynecol 115:134-140. https://doi.org/10.1097/AOG. 0b013e3181c391d7

55. Juliana NCA, Suiters MJM, Al-Nasiry S, Morre SA, Peters RPH, Ambrosino E (2020) The association between vaginal microbiota dysbiosis, bacterial vaginosis, and aerobic vaginitis, and adverse pregnancy outcomes of women living in sub-saharan africa: a systematic review. Front Public Health 8:567885. https://doi.org/ 10.3389/fpubh.2020.567885
56. van Oostrum N, De Sutter P, Meys J, Verstraelen H (2013) Risks associated with bacterial vaginosis in infertility patients: a systematic review and meta-analysis. Hum Reprod 28:1809-1815. https://doi.org/10.1093/humrep/det096

57. Haahr T, Zacho J, Brauner M, Shathmigha K, Skov Jensen J, Humaidan P (2019) Reproductive outcome of patients undergoing in vitro fertilisation treatment and diagnosed with bacterial vaginosis or abnormal vaginal microbiota: a systematic PRISMA review and meta-analysis. BJOG 126:200-207. https://doi.org/10. 1111/1471-0528.15178

58. Wiesenfeld HC, Hillier SL, Krohn MA, Amortegui AJ, Heine RP, Landers DV et al (2002) Lower genital tract infection and endometritis: insight into subclinical pelvic inflammatory disease. Obstet Gynecol 100:456-463. https://doi.org/10.1016/s00297844(02)02118-x

59. Hong X, Ma J, Yin J, Fang S, Geng J, Zhao H et al (2020) The association between vaginal microbiota and female infertility: a systematic review and meta-analysis. Arch Gynecol Obstet 302:569-578. https://doi.org/10.1007/s00404-020-05675-3

60. Atashili J, Poole C, Ndumbe PM, Adimora AA, Smith JS (2008) Bacterial vaginosis and HIV acquisition: a meta-analysis of published studies. AIDS 22:1493-1501. https://doi.org/10.1097/ QAD.0b013e3283021a37

61. Bautista CT, Wurapa EK, Sateren WB, Morris SM, Hollingsworth BP, Sanchez JL (2017) Association of bacterial vaginosis with chlamydia and gonorrhea among women in the U.S. Army Am J Prev Med 52:632-639. https://doi.org/10.1016/j.amepre.2016.09.016

62. Allsworth JE, Peipert JF (2011) Severity of bacterial vaginosis and the risk of sexually transmitted infection. Am J Obstet Gynecol 205(113):e111-116. https://doi.org/10.1016/j.ajog.2011.02.060

63. Rupp R, Rosenthal SL, Stanberry LR (2007) VivaGel (SPL7013 $\mathrm{Gel}$ ): a candidate dendrimer-microbicide for the prevention of HIV and HSV infection. Int J Nanomedicine 2:561-566

64. Tyssen D, Henderson SA, Johnson A, Sterjovski J, Moore K, La J et al (2010) Structure activity relationship of dendrimer microbicides with dual action antiviral activity. PLoS ONE 5:e12309. https://doi.org/10.1371/journal.pone.0012309

65. Bernstein DI, Stanberry LR, Sacks S, Ayisi NK, Gong YH, Ireland J et al (2003) Evaluations of unformulated and formulated dendrimer-based microbicide candidates in mouse and guinea pig models of genital herpes. Antimicrob Agents Chemother 47:37843788. https://doi.org/10.1128/AAC.47.12.3784-3788.2003

66. Gong E, Matthews B, McCarthy T, Chu J, Holan G, Raff J et al (2005) Evaluation of dendrimer SPL7013, a lead microbicide candidate against herpes simplex viruses. Antiviral Res 68:139-146. https://doi.org/10.1016/j.antiviral.2005.08.004

67. Jiang YH, Emau P, Cairns JS, Flanary L, Morton WR, McCarthy TD et al (2005) SPL7013 gel as a topical microbicide for prevention of vaginal transmission of SHIV89.6P in macaques. AIDS Res Hum Retroviruses 21:207-213. https://doi.org/10.1089/aid. 2005.21.207

68. Patton DL, Cosgrove Sweeney YT, McCarthy TD, Hillier SL (2006) Preclinical safety and efficacy assessments of dendrimerbased (SPL7013) microbicide gel formulations in a nonhuman primate model. Antimicrob Agents Chemother 50:1696-1700. https://doi.org/10.1128/AAC.50.5.1696-1700.2006

69. Abu-Zaid A, Alshahrani MS, Bakhsh H, Miski NT, Abuzaid M, Alomar O et al (2021) Astodrimer gel for treatment of bacterial vaginosis: A systematic review and meta-analysis of randomized controlled trials. Int J Clin Pract 75:e14165. https://doi.org/10. 1111/ijcp. 14165

70. Mundipharma Medical GmbH (2020) BETAFEM ${ }^{\circledR}$ BV Gel, instructions for use

Publisher's Note Springer Nature remains neutral with regard to jurisdictional claims in published maps and institutional affiliations. 